Original Research Paper

\title{
New Insights into the Pre-Concentration of Alunite from a Siliceous ore using Froth Flotation
}

\author{
${ }^{1}$ Fahimeh Dehghani, ${ }^{2}$ Halimeh Askari-Sabzkoohi and ${ }^{1}$ Tathagata Ghosh \\ ${ }^{l}$ Department of Mining and Geological Engineering, University of Alaska Fairbanks, AK, USA \\ ${ }^{2}$ Department of Mining Engineering, Islamic Azad University Science and Research Branch, Tehran, Iran
}

\author{
Article history \\ Received: 24-09-2020 \\ Revised: 31-10-2020 \\ Accepted: 17-11-2020 \\ Corresponding Author: \\ Fahimeh Dehghani \\ Department of Mining and \\ Geological Engineering, \\ University of Alaska Fairbanks, \\ AK, USA \\ Email: fdehghani@alaska.edu
}

\begin{abstract}
Alunite is the main non-bauxite source of aluminum. Due to the low Degrees Of Freedom (DOF) of alunite, froth flotation, as a preconcentration method, is a viable alternative to increase selectivity in downstream processes. The current study was aimed at investigating the pre-concentration of alunite using micro-flotation. In the first step, an optical microscope studies were done to determine DOF of alunite. In the next step, flotation tests were designed. The experiments were performed based on the surface charge differential between alunite and quartz using direct and reverse flotation. In the reverse flotation, $\mathrm{Ca}^{+2}$ and $\mathrm{Ba}^{+2}$ were used to activate the quartz surface. Anionic collector was used to float the gangue minerals. The highest grade and recovery using reverse flotation were 34.96 and $81.33 \%$, respectively. In the direct flotation, the surface of alunite was activated using $\mathrm{Ba}^{2+}, \mathrm{Ca}^{2+}$ and $F^{-}$. The optimum condition was achieved using $F^{-}$as an alunite activator for particles ranged $-37+25 \mu \mathrm{m}$ with the grade of $31.47 \%$. The grade and recovery were 50 and $89 \%$, respectively. All experiments were conducted in Hallimond Tube. During the experiments, several parameters were controlled.
\end{abstract}

Keywords: Alunite, Flotation, $\mathrm{HF}, \mathrm{NaF}, \mathrm{CaO}, \mathrm{BaCl}_{2}$

\section{Introduction}

Aluminum is the most abundant metal element and the third most abundant element on the earth. This metal because of its unique properties has high consumption in a wide variety of industries such as aerospace, building industries, transportation and consumer goods (Tabereaux and Peterson, 2014; Russell, 1981; Eshkalak et al., 2020). One of the main sources to extract aluminum is bauxite. The depletion of economical bauxite sources in the world and increasing of aluminum price, increasing aluminum demand in the world and non-availability of bauxite sources in various countries have led to attempts to find alternative sources for it (Haraldsson and Johansson, 2018; Cullen and Allwood, 2013; Milford et al., 2011). Thus, discovering and exploiting, extracting and processing of alternative sources have significant importance for the industries to provide their aluminum demands. All mentioned reasons have encouraged researchers around the world to find the solutions for this challenge.

The non-bauxite sources of aluminum are divided in two categories, namely, silicate and non-silicate. Silicate sources include water-based silicates (clays) and nonwater-based silicates (such as nepheline syenite). Nonsilicates such as alunite is one of the potential and alternative sources of alumina (Dixit and Miller, 1980; Smith et al., 1982).

The extraction of alumina from alunite has its own difficulties and disadvantages. They include (1) the low concentration of alumina in alunite: Alunite feed consists of two-third of gangue, mainly quartz and clay, which results in increased transportation costs as well as processing costs in hydrometallurgical circuits. (2) Significant losses of alumina and leaching agents. The most common technique for aluminum extraction from alunite is hydrometallurgical methods including calcination and leaching. Because the main gangue of alunite is quartz (around 40\%), these methods lead to the formation of sodium aluminosilicate and potassium aluminosilicate complexes. These complexes cause losing alumina and leaching agents during the process. (3) Because of alunite and its gunge properties, most methods are not applicable to preconcentrate it (Dehghani et al., 2019). The low differences in densities of alunite and its companion minerals such as clay and 
quartz make density-based separators such as jig, shaking table, Humphrey spiral and so on non-suitable. Moreover, due to the uniform distribution of grade in different size fractions, the use of sieve bend or cyclone is not useful. Among various processing methods, froth flotation seems to be a useful method (Eskanlou et al., 2019). However, the low Degree Of Freedom (DOF) of alunite makes froth flotation a complex method to purify alunite. In this study, it will be focused on the flotation as a pre-concentration method for the purification of alumina (Loest and Schaefer, 1978; Küçük and Gülaboğlu, 2002).

Koca and Koca (2000) studied the carrier flotation of alunite from kaolin in Bahkesir, Turkey. He used calcite as a carrier, sodium silicate $\left(\mathrm{Na}_{2} \mathrm{SiO}_{3}\right)$ as a dispersant and sodium oleate as a collector. Under the optimized condition, $57.95 \%$ of alunite was recovered. Selective flocculation was used to separate alunite (45\%) and quartz $(55 \%)$ from Utah alunite reserves. In order to do selective flocculation, $1 \%$ of magnetite with an average size of $5 \mu \mathrm{m}$ was added to the pulp. Then non-ionic flocculent of Poly Acrylamide was added to selectively flocculate quartz and magnetite. The disadvantage of this method was the significant amount of valuable mineral was mechanically trapped, especially when the percentage of solid in the pulp was more than $5 \%$. Another challenge was the sensitivity of selective flocculation because of the presence of other ions in the pulp. However, in the case of artificial mixtures of alunite and gangue minerals using both flotation and flocculation to separate alunite from gangue mineral were somewhat successful, but, the separation of natural ores using conventional methods were not satisfactory because of low degree of freedom of alunite (Ustaer and Gürgey, 1975). Taghiyev et al. (2019) used flotation method to enrich alunite ore. They improved the grade of alunite from $50-51$ to $60 \%$. Followed by, soda-alkaline method of alunite ore processing to purify alunite.

A limited number of researches have been performed in the field of pre concentration of alunite based on flotation method. None of them have reported the effect of the presence of fluoride ion on alunite flotation capability. In this study, micro-flotation was employed to process natural alunite ore using fluoride ions $\left(\mathrm{F}^{-}\right)$. The advantage of using the micro-flotation method is no changes happen in pulp components during the flotation process. Reverse and direct flotation were performed using $\mathrm{Ca}^{+2}$ and $\mathrm{Ba}^{+2}$ as activator. In addition, the effectiveness of various parameters on flotation of alunite such as $\mathrm{pH}$, particle size, collector type and concentration were considered.

\section{Materials and Methods}

\section{Materials}

The representative sample was obtained from Haft Sandogh alunite deposit, Iran, where the reserve was estimated to be about 500 MT of alunite with the grade above $20 \%$. Chemical and mineralogical analyses were done by X-Ray Fluorescence (XRF) spectrometry and X-Ray Diffraction (XRD) analysis methods, respectively. The mineralogical analyses indicated the sample had more alunite than quartz and more quartz than kaolinite. The results of the chemical and mineralogical analyses of samples are given in Table 1 and Fig. 1. Table 2 represents the chemicals that were used in the froth flotation process. All chemicals except Sulfonate (manufactured by CYTEC) are manufactured by Merck Company.

Table 1: Chemical composition of the sample by the XRF technique (Wt \%)

\begin{tabular}{llllll}
\hline $\mathrm{SiO}_{2}$ & $\mathrm{SO}_{3}$ & $\mathrm{Al}_{2} \mathrm{O}_{3}$ & $\mathrm{~K}_{2} \mathrm{O}$ & $\mathrm{Na}_{2} \mathrm{O}$ & $\mathrm{CaO}$ \\
44.41 & 20.04 & 19.7 & 4.55 & 0.88 & 0.85 \\
$\mathrm{MgO}$ & $\mathrm{Fe}_{2} \mathrm{O}_{3}$ & $\mathrm{MnO}_{2}$ & $\mathrm{TiO}_{2}$ & $\mathrm{P}_{2} \mathrm{O}_{5}$ & $\mathrm{~L}$ \\
0.74 & 0.6 & 0.46 & 0.25 & 0.24 & 7.2 \\
\hline
\end{tabular}

Table 2: Type and dosage of chemicals used in the froth flotation process

\begin{tabular}{|c|c|c|}
\hline Type of chemicals & The effect of chemicals & Dosage \\
\hline Sodium hydroxide $(\mathrm{NaOH})$ & $\mathrm{pH}$ modifier & Until $\mathrm{pH}$ adjusts \\
\hline Hydrofluoric acid (HF) & pH modifier, Surface activator (it imposes negative charge on alunite surface) & Until $\mathrm{pH}$ adjusts \\
\hline Sodium fluoride & It imposes negative charge on alunite surface & $1 * 10^{-2} \mathrm{~mol} / \mathrm{l}$ \\
\hline Armac C & cationic collector & $1500 \mathrm{gr} / \mathrm{ton}$ \\
\hline AERO Promoter $801^{\mathrm{I}}$ & Anionic collector & $300 \mathrm{mg} / \mathrm{kg}$ \\
\hline Sodium Silicate $\Pi$ & Quartz depressant & $1250 \mathrm{gr} / \mathrm{ton}$ \\
\hline Sodium hex metaphosphate & Alunite depressant & \\
\hline Pine oil & Frother & $2-10$ drops \\
\hline Methyl Isobutyl Carbinol (MIBC) & Frother & $2-10$ drops \\
\hline Barium chloride & Quartz activator & $1 * 10^{-3} \mathrm{kmol} / \mathrm{m}^{3}$ \\
\hline Calcium Oxide & Quartz activator & $1 * 10^{-3} \mathrm{kmol} / \mathrm{m}^{3}$ \\
\hline
\end{tabular}

I These sulfonates are manufactured by CYTEC

${ }^{\Pi} \mathrm{Na}_{2} \mathrm{SiO}_{3}$

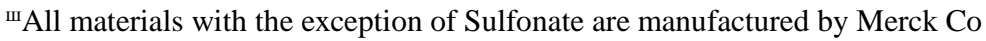




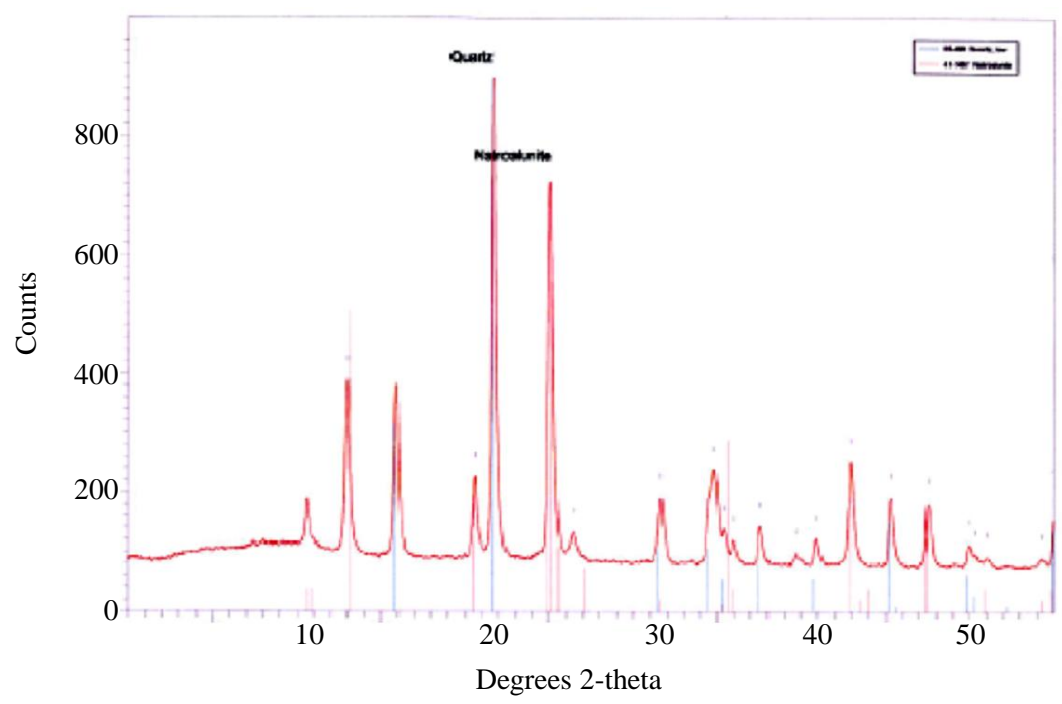

Fig. 1: XRD studies for the representative samples

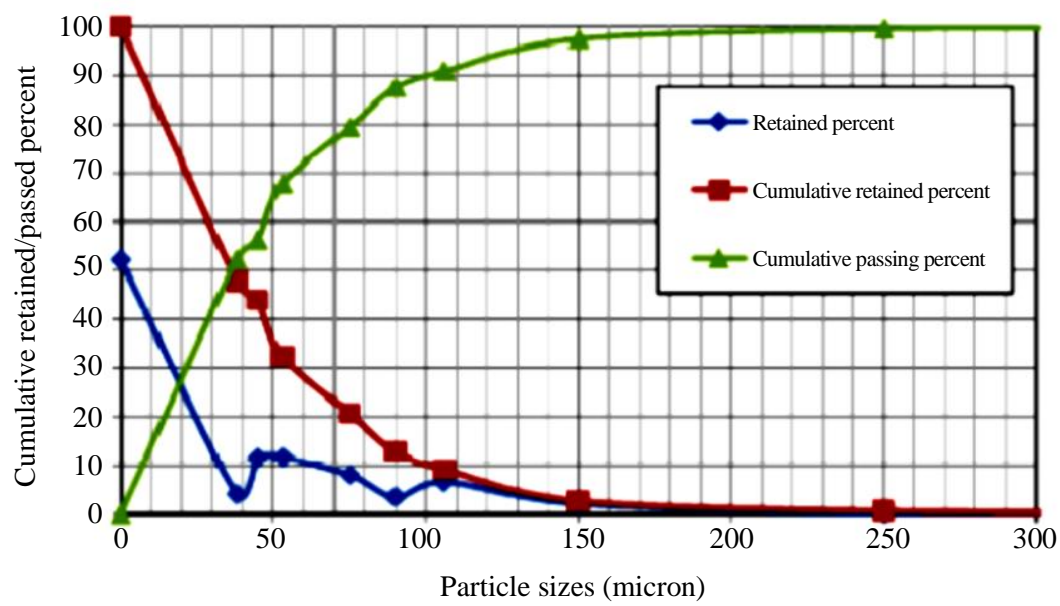

Fig. 2: Cumulative passing and retained percent of ore after 20 min grinding by ball mill

\section{Crashing and Grinding Tests}

Samples were crushed in a jaw crusher, a cone crusher and a roll crusher to produce particles with a size of $-2380+841 \mu \mathrm{m}$. In the next step, the samples were ground in a laboratory-scale Denver ball mill of $200 \mathrm{~mm}$ internal diameter, the volume of $950 \mathrm{~cm}^{3}$, loaded with 6 steel balls with $42 \mathrm{~mm}$ diameter, 21 balls with $31 \mathrm{~mm}$ diameter and 42 balls with $25 \mathrm{~mm}$ diameter and a mass load of $1000 \mathrm{gm}$. The grinding time in the ball mill was $20 \mathrm{~min}$. The particle size distribution of ball mill product is given in Fig. 2. The ball mill products were divided into four fractions using a shaker sieve. Fractions are including $-74+44,-44+37,-37+25,-25 \mu \mathrm{m}$.

\section{Optical Microscope Studies}

Before preparing samples for optical microscope studies, iron was removed from the sample. Although the iron content in the samples is only $1 \%$, it has negative effects on the quartz surface and consequently on the flotation process. The representative samples were prepared for optical microscope studies for each size fraction. The microscope studies presented the particles $<44 \mu \mathrm{m}$ have low Degree Of Freedom (DOF) for quartz and alunite. Thus, the froth flotation process is not appropriate for these sizes. Results showed DOF for minerals of $-44+37 \mu \mathrm{m}$ fraction is about $40 \%,-37+25 \mu \mathrm{m}$ is about $60 \%$ and $-10 \mu \mathrm{m}$ is $100 \%$ (Fig. 3). However, the DOF of $-10 \mu \mathrm{m}$ is $100 \%$, but due to the problems of ultrafine particles in flotation, they are not appropriate for the froth flotation process. According to the DOF results and appropriate particle size for froth flotation, the particles with size of $-37+25 \mu \mathrm{m}$ were selected for the next step of the experiments. 

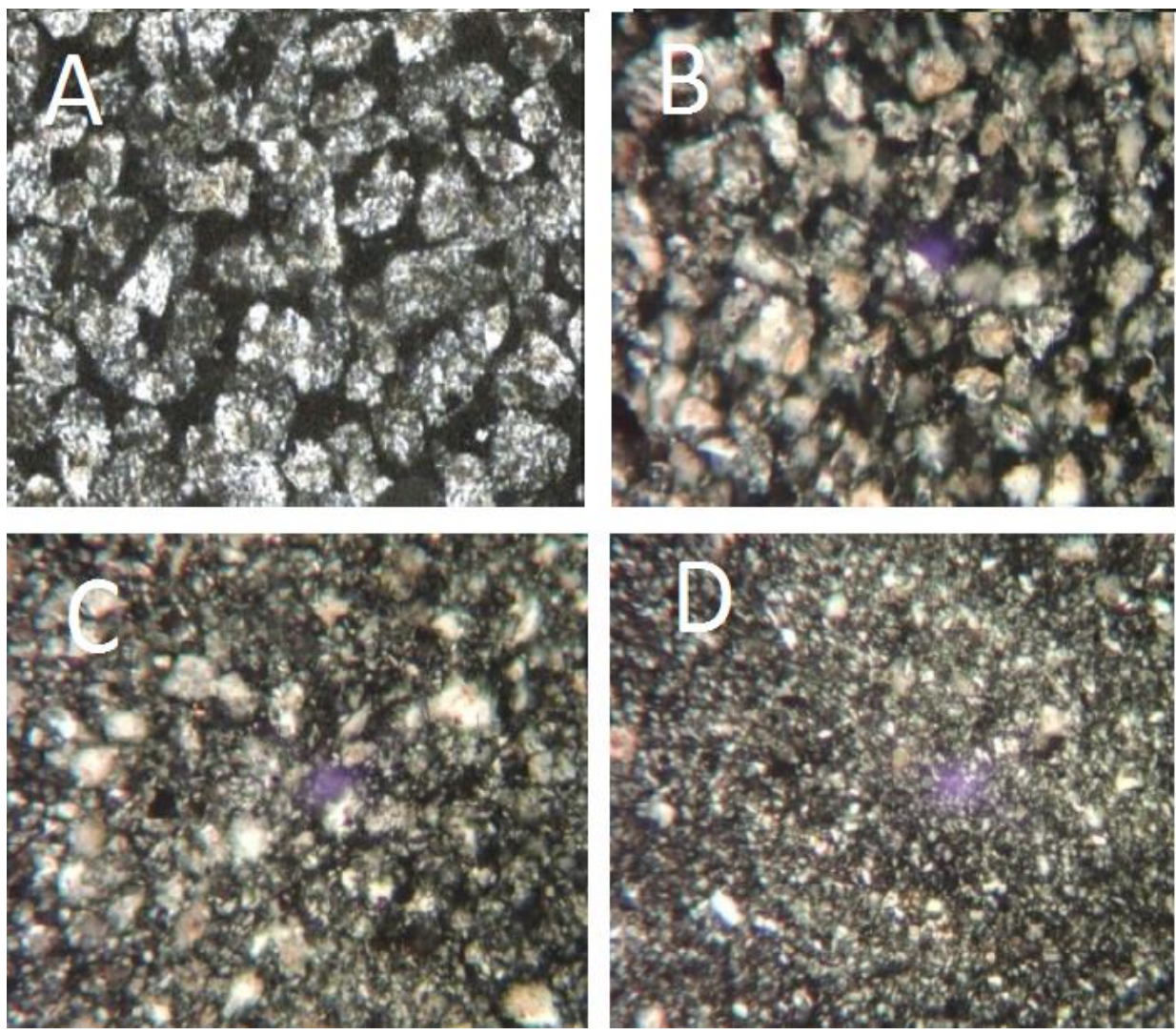

Fig. 3: Optical microscope studies, (A) $-74+44 \mu \mathrm{m}$, (B) $-44+37 \mu \mathrm{m},(\mathrm{C})-37+25 \mu \mathrm{m}$, (D) $-25 \mu \mathrm{m}$

\section{Methods}

To perform micro-flotation tests, a modified Hallimond tube was used. This tube was made up of Pyrex glass with $100 \mathrm{~mL}$ volume. A filter was used at the bottom of the cell to do airflow. The advantage of this tube is that there is no change in pulp components such as changes in dosage of collector, depressant and activator during the flotation process. Before the aeration process, particles are mixed carefully with the help of a magnet. Airflow entered into the cell, the hydrophobic particles were attached to the bubbles. Bubbles carried on particles to the surface. When the bubbles arrived at the surface, they burst and the particles fell into the chamber. In the last step, they were collected from the chamber by opening the corresponding valve. Figure 4 shows the layout for the modified Hallimond tube.

A during flotation tests, solid\% was 10 . The $\mathrm{pH}$ was adjusted using $\mathrm{NaOH}$ or $\mathrm{HF}$, followed by the addition of depressants, activators, collectors and frother. The preparation time was $10 \mathrm{~min}$. The pulp aeration and the froth removal were done for $5 \mathrm{~min}$. The concentration of alunite for each flotation test was dried and analyzed using XRF to get the grade. The recovery was calculated using the following equation (Rahimi et al., 2012; Rezai et al., 2010; Dehghani et al., 2013):
$R \%=\frac{C \times c}{F \times f} \times 100$

where, $C$ is the weight of the concentration, $c$ is the grade of the concentration, $F$ is the weight of the feed and $f$ is the grade of the feed.

In this study two types of experiments were performed for flotation of alunite.

Reverse Alunite Micro-Flotation using $\mathrm{Ca}^{+2}$ and $\mathrm{Ba}^{+2}$ as an Activator

In the first phase, $\mathrm{Ca}^{+2}$ and $\mathrm{Ba}^{+2}$ were used to activate the quartz surface. Anionic collector was used at $\mathrm{pH}=$ 12 (El-Salmawy et al., 1993). The $\mathrm{pH}$ is adjusted using $\mathrm{NaOH}$ followed by the addition of $\mathrm{BaCl}_{2}$. The pulp was agitated with the magnet for $20 \mathrm{~min}$. The aero promoter 801 was added as a collector. The preparation time was $10 \mathrm{~min}$. The aeration was done for $5 \mathrm{~min}$ and froth was removed.

Direct Alunite Miro-Flotation using ion F-

$$
\begin{aligned}
& H F \rightleftharpoons H^{+}+F^{-} \quad K_{1}=6.67 * 10^{-4} \quad \text { mol. } l^{-1} \\
& H^{+}+2 F^{-} \rightleftharpoons H F_{2}^{-} \quad K_{2}=5.7 * 10^{3} \quad \text { mol. } l^{-2}
\end{aligned}
$$




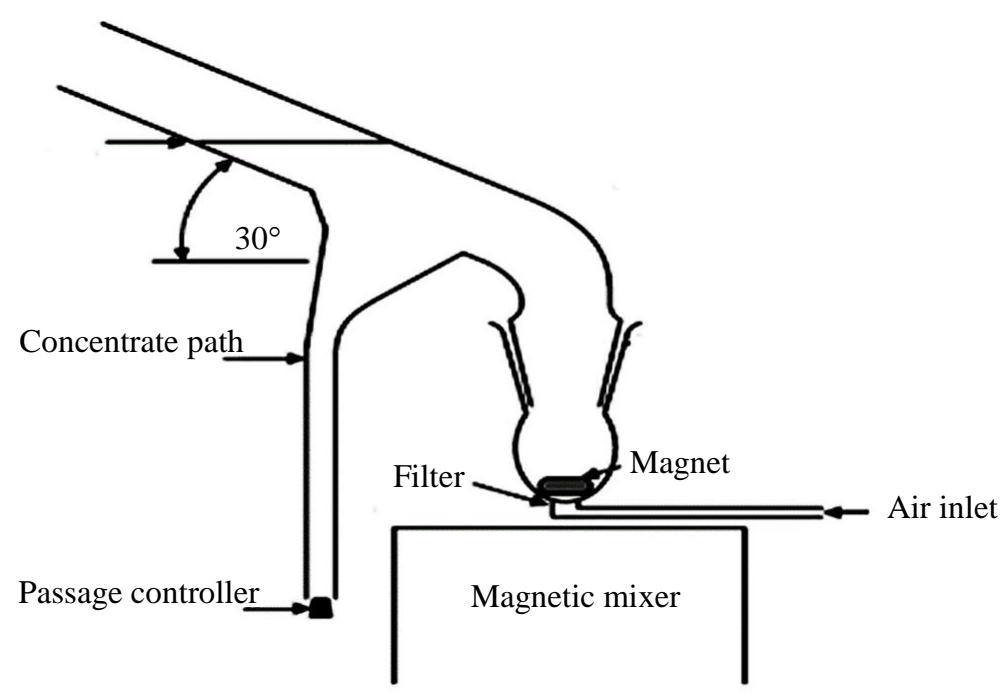

Fig. 4: Layout of the modified Hallimond tube (Bulut et al., 2014)

$\mathrm{HF}$ and $\mathrm{SiO}_{2}$ (quartz) react to form hexafluorosilicic acid, which in turn results in the formation of fluorosilicate ions $\left(\mathrm{SiF}_{6}{ }^{-2}\right)$. These reactions do not change the surface charge of the quartz. Therefore, quartz in the presence of a fluoride ion is not activated. Instead, $\mathrm{SiF}_{6}{ }^{-2}$ will be adsorbed by an aluminum surface and makes its surface negatively charged (Equation 4):

$>\mathrm{Al}-\mathrm{OH}+\mathrm{SiF}_{6}^{-2} \rightleftharpoons \mathrm{Al}-\mathrm{SiF}_{6}^{-}+\mathrm{OH}^{-}$

Finally, amine ions (collector) are absorbed on the surface layer with the help of electrostatic forces. During this process, the formation of $\mathrm{RNH}_{3} \mathrm{SiF}_{6}{ }^{-2}$ is possible. This compound undergoes the ion exchange process with hydroxyl groups (Equation 5):

$$
>\mathrm{Al}-\mathrm{OH}+\mathrm{RNH}_{3} \mathrm{SiF}_{6}^{-2} \rightleftharpoons-\mathrm{Al}-\mathrm{SiF}_{6} \mathrm{RNH}_{3}+\mathrm{OH}^{-}
$$

Both mechanisms result in the formation of similar negatively charged surface compounds (Kashkai and Babaev, 1969). In these series of experiments, $F^{-}$(in the form of $\mathrm{NaF}$ and $\mathrm{HF}$ ) was used as the Alunite surface activator. Fluoride ion imposes negative charge on the alunite surface which makes the alunite surface ready to absorb cationic collector. One-gram of sample was mixed with $100 \mathrm{~mL}$ distilled water for one minute. $H F$ was used as a pH modifier and alunite surface activator.

In the next series of experiments, in order to produce $F^{-}$, first of all, the $\mathrm{pH}$ was adjusted using $\mathrm{H}_{2} \mathrm{SiF}_{6}$, followed by the addition of $\mathrm{NaF}$. The pulp was agitated with the magnet for $20 \mathrm{~min}$. Armac C ((Coco-alkylamine-acetate (C-N; R22-R34-R50)) was added as a collector and the preparation time was $10 \mathrm{~min}$. The aeration was done for $5 \mathrm{~min}$. Froth was removed for 5 min. Finally, concentrates and tailings were analyzed.

\section{Results and Discussion}

The main purpose of this study was to preconcentrate alunite. Representative Samples were selected for both direct and reverse flotation methods. Sieve analysis was done for the feed and the grade was obtained for each size. The results were given in Table 3. However, the particle with sizes $-25 \mu \mathrm{m}$ has the highest grade and DOF, but they are not appropriate for flotation tests. In this series of experiments, a number of flotation tests were performed on $-37+25 \mu \mathrm{m}$ size fraction because DOF for this fraction is around $60 \%$. Moreover, particle sizes are suitable for the flotation process (Alunite grade is $31.43 \%$ ). Zeta potential was measured for alunite samples at different $\mathrm{pH}$ and temperature. The results are shown in Table 4. Experiments were performed for reverse and direct flotation. Finally, the effective parameters of each category were investigated and optimized.

\section{Reverse Alunite Micro-Flotation using $\mathrm{Ca}^{+2}$ and} $\mathrm{Ba}^{+2}$ as Activator

The purpose of this step is to sink alunite and float other minerals such as quartz. Therefore, it is expected the grades of alunite in the tailings to be higher than the concentrate (floated material) (Eskanlou et al., 2018). The results are shown in the Table 5 . As it can be seen in Table $5, \mathrm{Ca}^{+2}$ as an activator has a negative effect on the reverse flotation of alunite. The grade and recovery are 23.36 and $46.6 \%$, respectively. $\mathrm{Ca}^{+2}$ ions are adsorbed by both surfaces of quartz and alunite, which makes the flotation a non-selective process. Thus, both quartz and alunite behave similarly in the process (Küçük and Gülaboğlu, 2002; Apte et al., 1988). In the next set of experiments, $\mathrm{BaCl}_{2}$ was used as an activator. It had a 
positive effect on the flotation as the grade increased to $34.96 \%$ and recovery to $81.33 \%$ (Table 6). Although, by adding $\mathrm{BaCl}_{2}$, the grade and recovery increased compared to the previous step, but the result is not acceptable from an economic point of view. Therefore, the next series of experiments were performed.

\section{Direct Alunite Micro-Flotation using ion $F^{-}$}

In this series of experiments, micro-flotation tests were performed for a variety of $\mathrm{pH}$ including $\mathrm{pH}=2$, 2.5, 3 and 4. HF was used as a $\mathrm{pH}$ modifier and alunite activator. As can be seen from Table 7 and Fig. 5, by increasing $\mathrm{pH}$, the grade and recovery of the flotation process decreased. Due to more consumption of HF to achieve lower $\mathrm{pH}$, the alunite surface was more negative compared to higher $\mathrm{pH}$. Furthermore, at $\mathrm{pH}=$ 2 , the surface charge of quartz is close to zero because the Zero Point of Charge (ZPC) of quartz is 1.8 . Therefore, the cationic collector has a high tendency to adsorb alunite surface at lower $\mathrm{pH}$. The highest grade and recovery were obtained at $\mathrm{pH}=2,49.9$ and $88.9 \%$ respectively. On the other hand, for higher $\mathrm{pH}$, the consumption of HF reduces. Consequently, the amount of $F^{-}$ions in the pulp will decrease. Thus, the negative charge of the alunite surface will decrease. Moreover, at higher $\mathrm{pH}$, the negative charge of the quartz surface increases. As a result, quartz can float using the cationic collector Armac C. By the flotation of quartz, final product grade was decreased.

Another series of tests were performed on coarser size fraction $(-63+44 \mu \mathrm{m})$ which is more profitable from the industrial point of view. Two different dosages of collector were used. The results are given in Table 7. Comparing Tables 7 and 8 shows by increasing the particle size, the alunite grade declines due to the lower DOF at coarser particles. Also, Table 8 demonstrates by increasing collector dosage, alunite grade and recovery will decrease. The highest amount of grade $(41.15 \%)$ and recovery $(62.89 \%)$ for $-63+44 \mu \mathrm{m}$ fraction were achieved at $\mathrm{pH}=2$ with $1500 \mathrm{~g} /$ ton of collector.

Table 3: Alunite grade in various fractions

\begin{tabular}{llc}
\hline Fraction $(\mu \mathrm{m})$ & Grade $(\%)$ & Weight $(\mathrm{g})$ \\
\hline+75 & 48.98 & 1603.81 \\
$-75+44$ & 34.34 & 386.03 \\
$-44+37$ & 38.08 & 132.73 \\
$-37+25$ & 31.43 & 41.35 \\
-25 & 71.47 & 364.71 \\
\hline
\end{tabular}

Table 4: Zeta potential of the samples at different $\mathrm{pH}$ and temperature

\begin{tabular}{llll}
\hline No. & Temperature $\left({ }^{\circ} \mathrm{C}\right)$ & $\mathrm{pH}$ & Zeta potential $(\mathrm{mV})$ \\
\hline 1 & 2.9 & 21 & 369 \\
2 & 7.2 & 24 & -35 \\
3 & 11.0 & 23 & -160 \\
\hline
\end{tabular}

Table 5: Alunite concentration in the present of $\mathrm{CaO}$

\begin{tabular}{lllllll}
\hline & $\mathrm{pH}$ & Weight $(\mathrm{g})$ & Alunite weight $(\mathrm{g})$ & Quartz weight $(\mathrm{g})$ & Alunite grade $(\%)$ & Alunite recovery \\
\hline Conc. & 12 & 1.71 & 0.55 & 1.16 & 32.36 & 53.4 \\
Tailing & 12 & 2.046 & 0.48 & 1.566 & 23.36 & 46.6 \\
\hline
\end{tabular}

Table 6: Alunite concentration in the present of $\mathrm{BaCl}_{2}$

\begin{tabular}{lllllll}
\hline & $\mathrm{pH}$ & Weight $(\mathrm{g})$ & Alunite weight $(\mathrm{g})$ & Quartz weight $(\mathrm{g})$ & Alunite grade $(\%)$ & Alunite recovery \\
\hline Conc. & 12 & 1.075 & 0.323 & 0.745 & 30.68 & 19.67 \\
Tailing & 12 & 2.925 & 1.022 & 1.9 & 34.96 & 81.33 \\
\hline
\end{tabular}

Table 7: Alunite grade in different $\mathrm{pH}$ for $-25+37 \mu \mathrm{m}$ size fraction

\begin{tabular}{lllllll}
\hline & $\mathrm{pH}$ & Weight $(\mathrm{g})$ & Alunite weight $(\mathrm{g})$ & Quartz weight $(\mathrm{g})$ & Alunite grade $(\%)$ & Alunite recovery \\
\hline Conc. & 2 & 2.061 & 1.03 & 1.033 & 49.9 & 88.9 \\
Tailing & 2 & 1.619 & 0.46 & 1.53 & 28.76 & 11.1 \\
Conc. & 2.5 & 1.249 & 0.52 & 0.739 & 41.24 & 50.7 \\
Tailing & 2.5 & 1.984 & 0.596 & 0.578 & 30.13 & 49.3 \\
Conc. & 3 & 1.418 & 0.56 & 0.86 & 39.22 & 50.4 \\
Tailing & 3 & 2.095 & 0.64 & 1.46 & 30.44 & 49.6 \\
Conc. & 4 & 1.536 & 0.56 & 0.98 & 36.32 & 53.46 \\
Tailing & 4 & 1.784 & 0.55 & 1.23 & 30.97 & 46.54 \\
\hline
\end{tabular}

Table 8: Alunite grade in $\mathrm{pH}=2$, fraction: $44+63 \mu \mathrm{m}$ with different dosage of collector

\begin{tabular}{|c|c|c|c|c|c|c|c|}
\hline & $\mathrm{pH}$ & Collector (g/ton) & Weight $(\mathrm{g})$ & Alunite weight $(\mathrm{g})$ & Quartz weight (g) & Alunite grade $(\%)$ & Alunite recovery \\
\hline Conc. & 2 & 1500 & 2.43 & 1 & 1.43 & 41.15 & 62.89 \\
\hline Tailing & 2 & 1500 & 2.00 & 0.59 & 1.41 & 29.49 & \\
\hline Conc. & 2 & 2250 & 2.26 & 0.91 & 1.35 & 40.2 & 53.84 \\
\hline Tailing & 2 & 2250 & 2.232 & 0.78 & 1.45 & 34.96 & \\
\hline
\end{tabular}




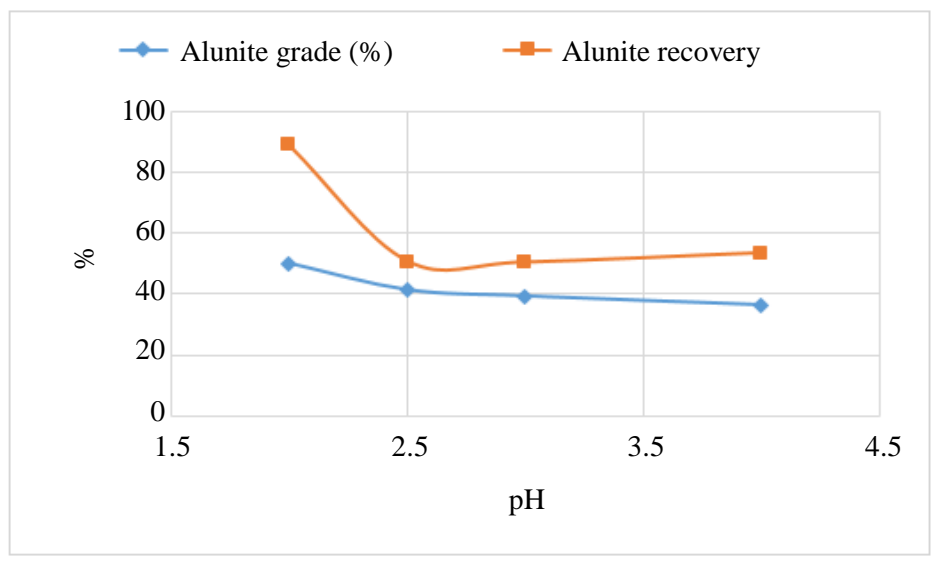

Fig. 5: Effect of $\mathrm{pH}$ on the grade and recovery of alunite, $\mathrm{HF}$ as a $\mathrm{pH}$ modifier and activator, $-25+37 \mu \mathrm{m}$ size fraction

In this research, alunite ore from Haft-Sandogh mine was used for flotation tests. However, the ore composition is dependent on the geology of the deposit, hence the ore characteristics varies from one mine to other. Generally, most of the gangue minerals associated with alunite are similar but there are few instances where they show variation. In adopting the results of this research for purification of other alunite deposits, researchers should perform mineralogical and DOF studies. Based on that, they can decide how to follow our procedure. For instance, since the main gangue associated with alunite is quartz, then flotation procedure described in this research can be applied. Conversely, if the gangue is different or there are other impurities, then the researched would decide which flotation producer.

\section{Conclusion}

In this study, the main minerals of the used ore deposit were alunite, quartz and kaolinite. Around 2/3 of alunite ore is gangue minerals. Quartz was the main gangue the ore accounting for around $44.41 \mathrm{wt} \%$. In order to decrease transportation and processing costs in hydrometallurgical circuits, pre-concentration methods were considered to purify alunite ore. DOF studies were done for the samples. DOF for minerals of $-44+37 \mu \mathrm{m}$ fraction is about $40 \%,-37+25 \mu \mathrm{m}$ is about $60 \%$. $100 \%$ liberation of alunite particles occurs when particles are grounded finer than $10 \mu \mathrm{m}$, but they are not appropriate for flotation. Alunite has a lower bond index compared to quartz, so during the comminution process, alunite is grounded to small size fractions faster than quartz. Consequently, quartz particles can be covered with alunite slimes. Slime coating of alunite particles with quartz particles significantly makes the selective flotation difficult, especially it has negative effects on reverse flotation.

Using $\mathrm{Ca}^{+2}$ as an activator in the flotation process had a negative effect on the result because $\mathrm{Ca}^{+2}$ was adsorbed by both surfaces of quartz and alunite. Consequently, it made the flotation process nonselective as both quartz and alunite had a similar behavior in the process. On the other hand, adding $\mathrm{BaCl}_{2}$ as an activator had a positive effect on the flotation. Using $\mathrm{BaCl}_{2}$ floated $81.33 \%$ of alunite with a grade of $34.9 \%$. However, by adding $\mathrm{BaCl}_{2}$, the grade and recovery will increase compared to using $\mathrm{Ca}^{+2}$, but it is not acceptable because of the low grade of the product. Using $F^{-}$ion as an activator of the alunite surface and a $\mathrm{pH}$ modifier imposed negative charge on the alunite surface. As a result, cationic collector was absorbed on an alunite surface. The highest amount of grade and recovery were obtained using HF. In this condition the grade and recovery were 49.9 and $88.3 \%$, respectively.

\section{Funding Information}

The authors wish to acknowledge support from Islamic Azad University Science and Research Branch and the University of Alaska Fairbanks for access to data used in this manuscript and financial supporting for conducting tests.

\section{Authors Contributions}

Fahimeh Dehghani and Halimeh AskariSabzekoohi: Conceived and designed the study, conducted the study and write the manuscript.

Tathagata Ghosh: Wrote the paper, review it and give comments to improve the work.

\section{Declaration of Competing Interest}

On behalf of all authors, the corresponding author states that there is no conflict of interest.

\section{References}

Apte, N. G., Kiran, E., \& Chernosky, J. V. (1988). Thermal decomposition of aluminium-bearing compounds. Journal of Thermal Analysis and Calorimetry, 34(4), 975-981. 
Bulut, G., Yenial, Ü., Emiroğlu, E., \& Sirkeci, A. A. (2014). Arsenic removal from aqueous solution using pyrite. Journal of Cleaner Production, 84, 526-532.

Cullen, J. M., \& Allwood, J. M. (2013). Mapping the global flow of aluminum: From liquid aluminum to end-use goods. Environmental science \& technology, 47(7), 3057-3064.

Dehghani, F., Rahimi, M., \& Rezai, B. (2013). Influence of particle shape on the flotation of magnetite, alone and in the presence of quartz particles. Journal of the Southern African Institute of Mining and Metallurgy, 113(12), 905-911.

Dehghani, F., Sabzkooh, H. A., Salarirad, M. M., \& Ghosh, T. (2019). Pre-concentration of alunite using froth flotation to improve recovery and grade. in SME Annual Conference \& Expo and CMA 121st National Western Mining Conference. Denver, Colorado, USA 24-27 February.

Dixit, S. G., \& Miller, J. D. (1980). Flotation chemistry of alunite oleate system. In AIME Anuel Meeting, SME, Nevada, USA.

El-Salmawy, M. S., Nakahiro, Y., \& Wakamatsu, T. (1993). The role of alkaline earth cations in flotation separation of quartz from feldspar. Minerals Engineering, 6(12), 1231-1243.

Eshkalak, K. E., Sadeghzadeh, S., \& Molaei, F. (2020). Aluminum nanocomposites reinforced with monolayer polyaniline $(\mathrm{C} 3 \mathrm{~N})$ : assessing the mechanical and ballistic properties. RSC Advances, 10(33), 19134-19148.

Eskanlou, A., Khalesi, M. R., \& Abdollahy, M. (2018). Bubble loading profiles in a flotation column. Physicochemical Problems of Mineral Processing, 54.

Eskanlou, A., Khalesi, M. R., Mirmogaddam, M., Hemmati Chegeni, M., \& Vaziri Hassas, B. (2019). Investigation of trajectory and rise velocity of loaded and bare single bubbles in flotation process using video processing technique. Separation Science and Technology, 54(11), 1795-1802.

Haraldsson, J., \& Johansson, M. T. (2018). Review of measures for improved energy efficiency in production-related processes in the aluminium industry-From electrolysis to recycling. Renewable and Sustainable Energy Reviews, 93, 525-548.
Kashkai, M. A., \& Babaev, I. A. (1969). Thermal investigations on alunite and its mixtures with quartz and dickite. Mineralogical Magazine, 37(285), 128-134.

Koca, S., \& Koca, H. (2000). Carrier flotation of alunite from kaolin clay. In Developments in Mineral Processing (Vol. 13, pp. C11-1). Elsevier.

Küçük, A., \& Gülaboğlu, M. Ş. (2002). Thermal decomposition of Şaphane alunite ore. Industrial \& engineering chemistry research, 41(24), 6028-6032.

Loest, K. W., \& Schaefer, J. T. (1978). U.S. Patent No. 4,075,068. Washington, DC: U.S. Patent and Trademark Office.

Milford, R. L., Allwood, J. M., \& Cullen, J. M. (2011). Assessing the potential of yield improvements, through process scrap reduction, for energy and $\mathrm{CO} 2$ abatement in the steel and aluminium sectors. Resources, Conservation and Recycling, 55(12), 1185-1195.

Rahimi, M., Dehghani, F., Rezai, B., \& Aslani, M. R. (2012). Influence of the roughness and shape of quartz particles on their flotation kinetics. International Journal of Minerals, Metallurgy and Materials, 19(4), 284-289.

Rezai, B., Rahimi, M., Aslani, M. R., Eslamian, A., \& Dehghani, F. (2010). Relationship between surface roughness of minerals and their flotation kinetics. In Proceedings of the XI International Mineral Processing and Technology Congress (pp. 232-238).

Russell, A. S. (1981). Pitfalls and pleasures in new aluminum process development. Metallurgical Transactions B, 12(2), 203-215.

Smith, K. A., Riemer, S. C., \& Iwasaki, I. (1982). Carbochlorination of Aluminum from non-bauxite sources. JOM, 34(9), 59-62.

Tabereaux, A. T., \& Peterson, R. D. (2014). Aluminum Production. Treatise on Process Metallurgy. Industrial Processes; ed: Seetharaman S, 839-917.

Taghiyev, E. I., Tagijev, E., \& Agajeva, L. (2019). Cost Effective Technology of Alunite Ore Processing. International Journal of Chemistry, 11(1), 36-42.

Ustaer, C., \& Gürgey, I. (1975). The separation of alunite in alunitic kaolin by selective flocculation. Clays and Clay Minerals, 23(6), 468-472. 